\title{
Sensorless Oscillation Control of a Suspended Load with Flywheels
}

\author{
Koichi Nishimura Student Member (Keio University, nishimu@sum.sd.keio.ac.jp) \\ Toshiaki Tsuji Member (Keio University, tsuji@kobalab.com) \\ Kouhei Ohnishi Senior Member (Keio University, ohnishi@sd.keio.ac.jp)
}

Keywords: flywheel, oscillation control, suspended load, disturbance observer, crane

Suspended loads are susceptible to disturbance such as wind. Oscillation control improves safeness and efficiency of loading and unloading. This study proposes a method of sensorless oscillation control of a suspended load.

We use a oscillation control device shown in Fig. 1. Two flywheels are installed on it. Only one dimensional oscillation is considered for simplification. The dynamic equation of suspended load is shown in (1).

$$
M \ddot{\phi}+I_{w}\left(\ddot{\theta_{1}}+\ddot{\phi}\right)+I_{w}\left(\ddot{\theta_{2}}+\ddot{\phi}\right)+G(\phi)=0
$$

$\phi$ is rotation angle of suspended load. $\theta_{1}$ and $\theta_{2}$ are rotation angle of flywheels. $M$ is total inertia of the system. $I_{w}$ is inertia of a flywheel. $G(\phi)$ is gravity torque. The second and third term of the left side of (1) mean reaction torque of flywheels represented by $\tau_{1}^{\text {reac }}$ and $\tau_{2}^{\text {reac }}$. Reaction torque of flywheels is applied for the oscillation control. We control the reaction torque as $\tau_{1}^{\text {reac }}=D_{1} \dot{\phi}$ and $\tau_{2}^{\text {reac }}=D_{2} \dot{\phi}$. Then, the dynamic equation includes damping term $\left(D_{1}+D_{2}\right) \dot{\phi}$, so oscillation control of a suspended load is realized.

Angular velocity value of a suspended load must be acquired for the oscillation control. In this research, we estimate angular velocity of the suspended load. Inertia torque observer is proposed as shown in (2). Inertia torque $I_{w n} \hat{\ddot{\phi}}$ is disturbance torque that occurs on flywheels as the suspended load is oscillating.

$$
I_{w n} \hat{\tilde{\phi}}=\frac{g_{i t}}{s+g_{i t}}\left(K_{t n} I_{a}-I_{w n} s \dot{\theta}-\hat{\tau}^{\text {fric }}\right)
$$

$\hat{\ddot{\phi}}$ is estimated angular acceleration. $g_{i t}$ is cutoff frequency of inertia torque observer. $K_{t}$ is torque constant. $I_{a}$ is input electric current.

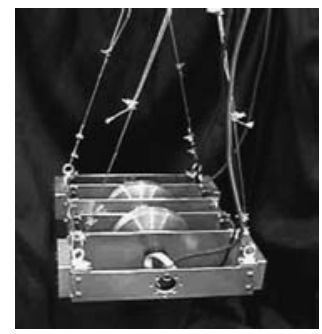

Fig. 1. Oscillation control device for suspended load $\hat{\tau}^{\text {fric }}$ is estimated friction torque. Subscript $n$ means nominal value. Estimated angular velocity of the suspended load $\hat{\dot{\phi}}$ is shown in (3).

$$
\hat{\dot{\phi}}=\frac{s^{2}}{\left(s+g_{H P F}\right)^{2}} \frac{g_{L P F}}{s+g_{L P F}} \frac{\hat{\phi}}{s} .
$$

$g_{H P F}$ and $g_{L P F}$ are cutoff frequency of high-pass filter and low-pass filter, respectively. Total control system of flywheels is shown in Fig. 2. Disturbance observer is adopted in this control system for robustness.

We made an oscillation control experiment of a suspended load with the proposed method. The experimental result is shown in Fig. 3. By using inertia torque observer, estimation of angular velocity value and oscillation control of the suspended load are achieved at the same time.

The proposed method will improve safeness and efficiency of loading and unloading.

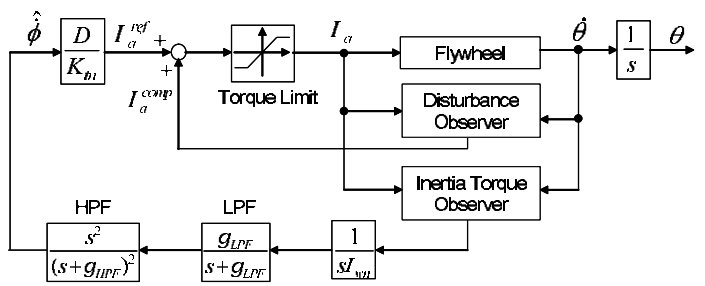

Fig. 2. Block diagram of controller

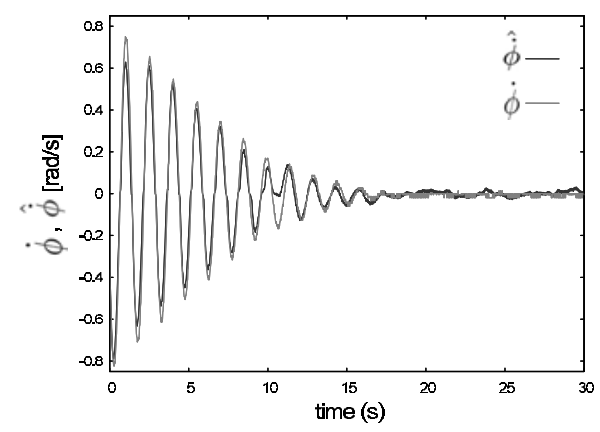

Fig. 3. Estimation of angular velocity 


\title{
フライホイールによる吊り荷のセンサレス振動制御
}

\author{
学 生員 西村 公一* 正員 辻 俊明* \\ 上級会員 大西 公平*
}

\section{Sensorless Oscillation Control of a Suspended Load with Flywheels}

Koichi Nishimura*, Student Member, Toshiaki Tsuji*, Member, Kouhei Ohnishi*, Senior Member

This study proposes a method of sensorless oscillation control of a suspended load. To suppress oscillation of a suspended load, we use flywheels as a control device. Reaction torque of flywheels is applied for the oscillation control. An angular velocity value of a suspended load must be acquired for the oscillation control. Therefore, a method to estimate the angular velocity value is indispensable. By conventional methods, the estimation and the oscillation control cannot be realized simultaneously in case of one flywheel. Hence, inertia torque observer is proposed. Inertia torque appears as a disturbance torque on flywheels when a suspended load is oscillating. The angular velocity value is calculated based on this inertia toque. By using inertia torque observer, estimation of the angular velocity value and oscillation control of a suspended load are achieved at the same time.

キーワード：フライホイール, 振動制御, 吊り荷, 外乱オブザーバ, クレーン

Keywords: flywheel, oscillation control, suspended load, disturbance observer, crane

\section{1. 序論}

港湾や建設現場では，コンテナや建築資材等の荷物の移 動にクレーンが広く利用されている。クレーンの吊り荷は 移動に伴う慣性や風などの外乱により，回転と横摇れを生 じやすい。よって吊り荷の積み下ろしの際には回転と横摇 れにより作業効率が落ちるだけでなく, 衝突による事故の 危険性が高くなる。また，港湾の使用料は時間に比例する ので，吊り荷の回転と横摇れを抑制し積み下ろし作業を効 率化できれば大規模なコスト削減も可能になる。このよう に安全面と経済面の両方から吊り荷の回転と横摇れを制御 することが必要とされている。

本論文では吊り荷の横摇れに焦点を置き，その制御につ いて述べる。以後の文中で用いる振動制御という表現は, 吊り荷の横摇れを抑圧するための制御を指す。

クレーンの操舵による吊り荷の振動制御法については今 日までにさまざまな研究がなされてきた ${ }^{(1) \sim(3) 。 し か し ， こ ~}$ れらの手法は吊り荷の横摇れを間接的に抑制するものであ り，風などの外乱に対する速応性に欠ける。このため吊り 荷に振動制御装置を搭載し直接吊り荷を制御する研究もな されている。例えば，コントロール・モーメント・ジャイ

\footnotetext{
*慶應義塾大学理工学部システムデザイン工学科

厂 223-8522 横浜市港北区日吉 3-14-1

Department of System Design Engineering, Keio University

3-14-1, Hiyoshi, Kouhoku-ku, Yokohama 223-8522
}

ロ (CMG) や慣性ロータを利用した吊り荷の振動制御手法 が提案されている(4)(5)。フライホイールは機構が簡単で製 造コストも低いが, $\mathrm{CMG}$ 等と比較して大きな反動トルク を得られないという久点を持つ。著者らはこの欠点を補う ためにフライホイールにブレーキ機構を搭載し, 出力トル クの増加を可能にする方法を提案した ${ }^{(6)}$ 。また，フライホ イールによる吊り荷の振動制御装置の性能を実寸大で評価 し，実用化の可能性を示した ${ }^{(7)}$ 。

吊り荷の振動制御を行うには, 吊り荷の横摇れを計測す る必要がある。その方法として画像センサ, 加速度センサ 等を用いることが考えられるが, これらは振動制御装置の コスト高や，サンプリング時間が長いことにより制御性能 の低下につながる。そこで, 著者らはフライホイールによ る吊り荷の振動制御装置を用いてフライホイールの角速度 応答からセンサレスで吊り荷の角速度を推定し, 吊り荷の 振動制御を行う手法を提案した ${ }^{(8)}$ 。しかし，この手法では 吊り荷の角速度推定と振動制御を 1 つのフライホイールで 同時に行うことは困難であるため, 振動制御用のフライホ イールの他に吊り荷の角速度推定用のフライホイールが必 要であった。吊り荷の角速度推定と振動制御を 1 つのフラ イホイールで同時に行うことができれば，実用に供せられ る。このフライホイールを振動制御に用いれば振動制御ト ルクの高出力化が可能になり, 機構の軽量化も図れる。

本論文では慣性トルク推定オブザーバを提案し，この技 術的課題を克服する。吊り荷を基準とする座標系において 
考えると,フライホイールの角速度応答值にはフライホイー ル自身の回転速度に加えて, 吊り荷の振動による変化が現 れる。このような角速度応答值の変化はフライホイールに 外乱が加わって生じると考えることができ，この外乱を慣 性トルクと呼ぶ。慣性トルク推定オブザーバとは外乱オブ ザーバ(9) の推定する外乱から慣性トルクを抽出するもので ある。得られた慣性トルクから吊り荷の角速度を推定でき る。慣性トルク推定オブザーバをフライホイールの制御系 に適用し，1つのフライホイールで吊り荷の角速度推定と 振動制御を同時に実現する。

本論文の構成は以下のとおりである。まず，第 2 章にお いて本研究で扱う吊り荷の実験システムのモデル化と解析 を行う。次に第 3 章で吊り荷の振動制御手法について述心 る。第 4 章では慣性トルク推定オブザーバを提案し, 1 つ のフライホイールで吊り荷の角速度推定と振動制御を同時 に行う手法について述べる。第 5 章では実験を行い，提案 手法の有效性を検証する。第 6 章ではトルクリプルに対す る提案手法のロバスト性を検証するため, シミュレーショ ンを行う。最後に第 7 章で結論を述べる。

\section{2. システムのモデル化と動力学}

本研究ではコンテナなどの吊り荷に振動制御装置を搭載 することを想定し，図 1 に示す実験システムを作成した。 実験システムは振動制御装置とおもりで構成されている。

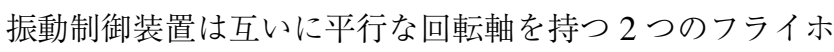
イールとそれを駆動するモータで構成されている。側面に おもりを取り付けることで質量及び慣性モーメントを増や し，振動制御装置を吊り荷に搭載した状態を再現している。

$\langle\mathbf{2} \cdot \mathbf{1}\rangle$ 吊り荷と振動制御装置のモデル化 実験シス テムを図 2 に示すようにモデル化した。単純化のため 1 次 元の振動のみを考慮する。吊り荷は支持点を中心に回転し, ワイヤの弛みや屈曲による吊り荷の姿勢変動や，支持点に 抒ける摩擦力はないものとする。 $\phi$ は吊り荷の回転角を表 す。フライホイールの回転軸は吊り荷の回転軸と平行であ る。フライホイールの駆動で生じる反動トルクにより吊り 荷の振動制御を行う。 $\theta$ はフライホイールの回転角を表し, 下添え字 1,2 はそれぞれ第 1,2 ホイールに対応しているこ とを表す。 $\theta$ は実際にはモータに取り付けたエンコーダで 測定するため, ワールド座標系ではなく振動制御装置の座 標系を基準とする。振動制御装置の基準点はフライホイー ルの回転軸上に設定する。lは吊り荷の支持点から振動制 御装置の基準点までの長さである。吊り荷全体の重心は振 動制御装置の基準点上に存在するものとする。

$\langle\mathbf{2} \cdot \mathbf{2}\rangle$ 吊り荷と振動制御装置の動力学 吊り荷と振 動制御装置の運動方程式は次式で表せる。

$$
\begin{aligned}
& M \ddot{\phi}+I_{w}\left(\ddot{\theta_{1}}+\ddot{\phi}\right)+I_{w}\left(\ddot{\theta_{2}}+\ddot{\phi}\right)+G(\phi)=0 \\
& M=m_{s} l^{2}+I_{o}+I_{d} \\
& G(\phi)=m_{s} g l \sin \phi \\
& m_{s}=m_{o}+m_{d}+2 m_{w}
\end{aligned}
$$

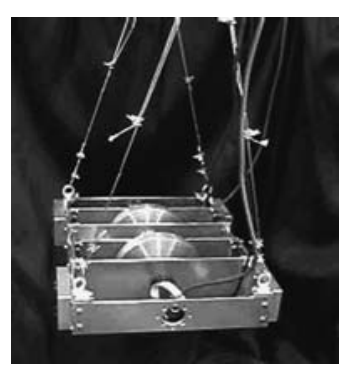

図 1 吊り荷の振動制御装置

Fig. 1. Oscillation control device for suspended load.

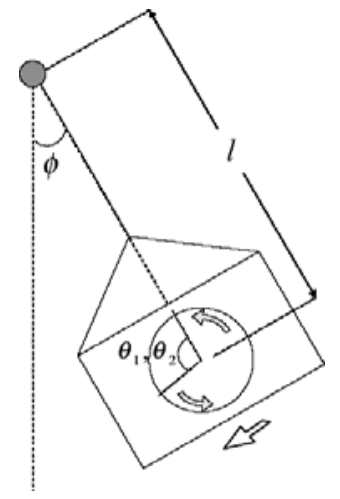

図 2 実験システムのモデル

Fig. 2. Model of experimental system.

$m$ は質量, $I$ は基準点回りの慣性モーメントを表す。下添え 字 $o, d, w$ はそれぞれ, 吊り荷, 振動制御装置, フライホイー ルを示す。 $g$ は重力加速度を表す。 $M$ は吊り荷の支持点回 りの慣性モーメント， $G(\phi)$ は重力によるトルク， $m_{s}$ は吊 り荷, 振動制御装置, フライホイールの質量の合計を表す。 (1) 式の $M \ddot{\phi}$ は吊り荷の慣性トルク, $I_{w}\left(\ddot{\theta_{1}}+\ddot{\phi}\right), I_{w}\left(\ddot{\theta_{2}}+\ddot{\phi}\right)$ はフライホイールの反動トルクを表す項である。

\section{3. 吊り荷の振動制御手法}

(1) 式第 2, 3 項はフライホイールの反動トルクであり, こ れらをそれぞれ $\tau_{1}^{\text {reac }}, \tau_{2}^{\text {reac }}$ で表す。

$$
M \ddot{\phi}+\tau_{1}^{\text {reac }}+\tau_{2}^{\text {reac }}+G(\phi)=0
$$

一方, これらの反動トルクはモータの運動方程式 (3), (4) で 表される。

$$
\begin{aligned}
& \tau_{1}^{\text {reac }}=\tau_{1}^{m}-\tau_{1}^{\text {fric }}=K_{t} I_{a 1}-\tau_{1}^{\text {fric }} . \\
& \tau_{2}^{\text {reac }}=\tau_{2}^{m}-\tau_{2}^{\text {fric }}=K_{t} I_{a 2}-\tau_{2}^{\text {fric }} .
\end{aligned}
$$

$\tau^{m}$ はモー夕の駆動トルク， $K_{t}$ はモータのトルク定数, $I_{a}$ は モータへの入力電流， $\tau^{\text {fric }}$ は摩擦トルクである。

吊り荷の振動制御は文献 (8) の方法を用いて行う。以下 にその方法を示す。(5), (6) 式を満たすようにフライホイー ルを制御し, 反動トルクが吊り荷の横摇れ時の粘性摩擦と 同等の効果を持つようにする。

$$
\tau_{1}^{\text {reac }}=D_{1} \dot{\phi}
$$




$$
\tau_{2}^{r e a c}=D_{2} \dot{\phi}
$$

減衰係数 $\left(D_{1}+D_{2}\right)$ のダンピング項をもつ振り子運動を (7) 式のように実現することで，吊り荷の振動を制御できる。

$$
M \ddot{\phi}+\left(D_{1}+D_{2}\right) \dot{\phi}+G(\phi)=0 .
$$

本論文では，このとき必要となる吊り荷の角速度 $\dot{\phi} の$ 值

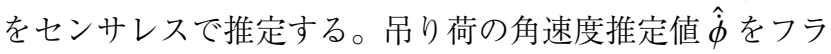
イホイールのコントローラへの入力とする。(5)，(6) 式よ り, モータへの入力電流参照值 $I_{a}^{\text {ref }}$ を決定するコントロー ラの方程式を(8)，(9) 式で与える。

$$
\begin{aligned}
I_{a 1}^{r e f} & =\frac{D_{1}}{K_{t n}} \hat{\phi} \\
I_{a 2}^{r e f} & =\frac{D_{2}}{K_{t n}} \hat{\phi}
\end{aligned}
$$

$K_{t n}$ はモータのトルク定数のノミナル值を表す。

\section{4. 吊り荷の角速度の推定手法}

(7) 式のように吊り荷の振動制御を行うためには, 吊り 荷の角速度 $\dot{\phi}$ の值を常に計測しておく必要がある。本章で は慣性トルク推定オブザーバを提案する。推定した慣性卜 ルクから吊り荷の角速度を求めることができる。このオブ ザーバをフライホイールの制御系に適用すると，1 つのフ ライホイールで吊り荷の角速度推定と振動制御を同時に行 えるようになる。

$\langle\mathbf{4} \cdot \mathbf{1}\rangle \quad$ 外乱オブザーバ＼cjkstart外乱オブザーバはモー夕に作 用する外乱トルクをセンサレスで推定する。ここでは，パ ラメータ変動とモデル化誤差による外乱も考慮する。モー 夕に加わる外乱トルク $\tau^{d i s}$ は (10) 式で表される。

$$
\begin{aligned}
\tau^{d i s}= & \left(I_{w}-I_{w n}\right) \ddot{\theta}-\left(K_{t}-K_{t n}\right) I_{a} \\
& +\tau^{f r i c}+\tau^{i t} \ldots \ldots \ldots \ldots \ldots
\end{aligned}
$$

下添え字の $n$ はノミナル值を示す。右辺の $\left(I_{w}-I_{w n}\right) \ddot{\theta}$ は フライホイールの慣性のモデル化誤差による外乱トルク， - $\left(K_{t}-K_{t n}\right) I_{a}$ はトルクリプルによる外乱トルク， $\tau^{\text {fric }}$ はフ ライホイールの駆動の際に生じる摩擦トルク， $\tau^{i t}$ は吊り荷 の振動によりモー夕に加わる慣性トルクを表す項である。 フライホイールの回転角 $\theta$ はモー夕に取り付けたエンコー ダで測定するため，振動制御装置の座標系を基準としてい る。これにより, 吊り荷が振動すると慣性トルクがモー夕 の外乱として生じる。

外乱を(10) 式で表すと, モータのノミナルな運動方程式 は (11) 式で示される。

$$
I_{w n} \ddot{\theta}=K_{t n} I_{a}-\tau^{d i s}
$$

(11) 式に基づき, 外乱オブザーバは (12) 式により外乱卜 ルクを推定する。

$$
\hat{\tau}^{d i s}=\frac{g_{d i s}}{s+g_{d i s}}\left(K_{t n} I_{a}-I_{w n} s \dot{\theta}\right) .
$$

$\hat{\tau}^{d i s}$ は外乱トルク $\tau^{d i s}$ の推定值を表す。 $g_{d i s}$ は外乱オブザー

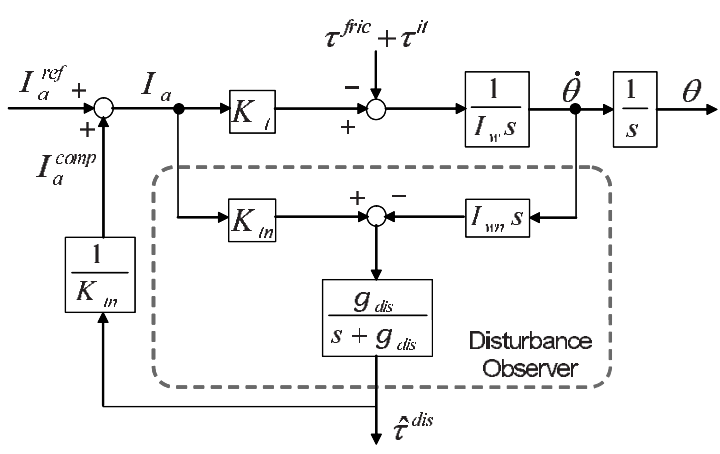

図 3 外乱オブザーバ

Fig. 3. Disturbance observer.

バの遮断角周波数である。外乱オブザーバのブロック線図 を図 3 に示す。本論文では推定した外乱トルクのフィード バックループを制御系に加え，外乱に対するロバスト性を 得ている。

(5)，(6) 式を満たすようにフライホイールを制御するた めには，(3)，(4) 式より

$$
D \dot{\phi}=K_{t} I_{a}-\tau^{\text {fric }}
$$

が成立しなければならない。すなわち，外乱才ブザーバは 摩擦卜ルク $\tau^{f r i c}$ は補償するが慣性トルク $\tau^{i t}$ を補償しない ように設計しなければならない。慣性トルクの角周波数は 吊り荷の振動の角周波数 $\omega_{n}=\sqrt{\frac{g}{l}}$ と同じであるから, 外乱 オブザーバの遮断角周波数 $g_{d i s}$ は $\omega_{n}$ よりも低く設定する。

$\langle\mathbf{4} \cdot \mathbf{2}\rangle \quad$ 慣性トルク推定オブザーバ＼cjkstart外乱オブザーバ の機能は外乱を補償することのみではない。摩擦や慣性変 動といった機械システム内部の外乱を事前に同定しておき, 外乱トルクとの值の差を求めることでシステムの外部から 受ける力を推定できる。外乱オブザーバのこのような機能 はマニピュレータ等が環境と接触する際に受ける反力の推 定にしばしば用いられ，反力推定オブザーバ(10) とよばれて いる。ここでは外乱オブザーバのシステム外部の外乱推定 機能を用いて，(10) 式で示したモー夕に加わる外乱トルク $\tau^{d i s}$ に含まれる慣性トルク $\tau^{i t}$ を抽出し, 吊り荷の角速度 $\dot{\phi}$ を推定する。(10) 式においてフライホイールの慣性モーメ ントは一定でモデル化誤差はないものとし, $\left(I_{w}-I_{w n}\right) \ddot{\theta}=0$ とする。トルクリプルによる外乱トルクは無視できるもの とし， $\left(K_{t}-K_{t n}\right) I_{a}=0$ であるとする。また, 同定試験を行 いフライホイールの摩擦トルクの推定值 $\hat{\tau}^{\text {fric }}$ をらかじめ 求めておく。

(10)，(11) 式に基づき, 慣性トルク推定オブザーバを (14) 式に示すように構成する。

$$
\hat{\tau}^{i t}=\frac{g_{i t}}{s+g_{i t}}\left(K_{t n} I_{a}-I_{w n} s \dot{\theta}-\hat{\tau}^{f r i c}\right) .
$$

$\hat{\tau}^{i t}$ は慣性トルクの推定值を表す。 $g_{i t}$ は慣性トルク推定才 ブザーバの遮断角周波数である。 $\tau^{i t}$ を正確に抽出するため には, $g_{i t}$ は $\tau^{i t}$ の角周波数, すなわち吊り荷の振動の角周 波数 $\omega_{n}$ よりも高い角周波数で，かつ，できるだけ低く設 


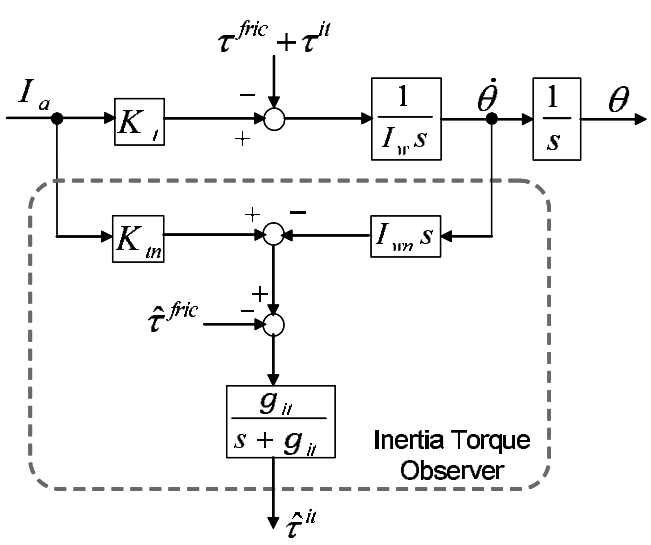

図 4 慣性トルク推定オブザーバ

Fig. 4. Inertia torque observer.

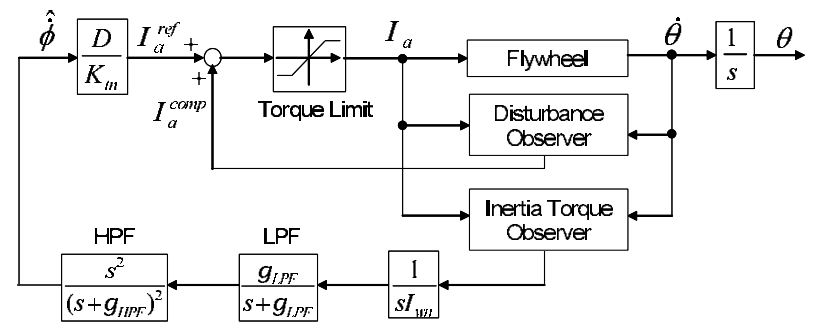

図 5 制御系のブロック線図

Fig. 5. Block diagram of controller.

定する必要がある。慣性トルク推定オブザーバのブロック 線図を図 4 に示す。

吊り荷の角加速度の推定值 $\hat{\dot{\phi}}$ は推定した慣性トルクから (15) 式により求められる。

$$
\hat{\ddot{\phi}}=\frac{\hat{\tau}^{i t}}{I_{w n}}
$$

吊り荷の角速度の推定值 $\hat{\dot{\phi}}$ は (16) 式で表される。

$$
\hat{\dot{\phi}}=\frac{s^{2}}{\left(s+g_{H P F}\right)^{2}} \frac{g_{L P F}}{s+g_{L P F}} \frac{\hat{\phi}}{s}
$$

$g_{H P F}, g_{L P F}$ はそれぞれハイパスフィルタ, ローパスフィル 夕の遮断角周波数である。残留している高周波のノイズを 除去するため, $g_{L P F}$ は吊り荷の振動の角周波数 $\omega_{n}$ よりも 高く設定する。苔を積分したあとに発生するオフセットと ランプ状に累積していく誤差を取り除くために，2次のハ イパスフィルタを用いる。吊り荷の角速度を正確に抽出す

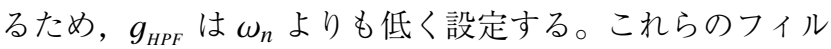
夕は推定誤差を低減するために非常に重要である。

外乱オブザーバ，慣性トルク推定オブザーバを用いてフ ライホイールの制御系を図 5 のように構成する。この制御 系により 1 つのフライホイールで吊り荷の角速度推定と振 動制御を同時に行えるようになる。

\section{5. 実験}

本論文で提案した慣性トルク推定オブザーバによる吊り
表 1 実験装置のパラメータ

Table 1. Parameters of experimental system.

\begin{tabular}{c|lr|l}
\hline$I_{o}$ & Object MOI & {$\left[\mathrm{kgm}^{2}\right]$} & 0.0795 \\
$I_{d}$ & Device MOI & {$\left[\mathrm{kgm}^{2}\right]$} & 0.0206 \\
$I_{w}$ & Wheel MOI & {$\left[\mathrm{kgm}^{2}\right]$} & 0.00322 \\
$m_{s}$ & Total weight & {$[\mathrm{kg}]$} & 13.829 \\
$m_{o}$ & Object weight & {$[\mathrm{kg}]$} & 5.515 \\
$m_{d}$ & Device weight & {$[\mathrm{kg}]$} & 6.054 \\
$m_{w}$ & Wheel weight & {$[\mathrm{kg}]$} & 1.130 \\
$l$ & Pendulum length & {$[\mathrm{m}]$} & 0.6 \\
$K_{t}$ & Torque constant & {$[\mathrm{Nm} / \mathrm{A}]$} & 0.0603 \\
$I_{\max }$ & Maximum electric current & {$[\mathrm{A}]$} & 3.33 \\
$\theta_{\max }$ & Maximum flywheel velocity & {$[\mathrm{rad} / \mathrm{s}]$} & 160.0 \\
\hline
\end{tabular}

表 2 制御系のパラメータ

Table 2. Parameters of controller.

\begin{tabular}{c|lr|l}
\hline$D$ & Damping factor & {$[\mathrm{Nms}]$} & 5.0 \\
$g_{H P F}$ & Cutoff frequency of high-pass filter & {$[\mathrm{rad} / \mathrm{s}]$} & 1.0 \\
$g_{L P F}$ & Cutoff frequency of low-pass filter & {$[\mathrm{rad} / \mathrm{s}]$} & 250.0 \\
$g_{d i s}$ & Cutoff frequency of disturbance observer & {$[\mathrm{rad} / \mathrm{s}]$} & 1.0 \\
$g_{i t}$ & Cutoff frequency of inertia torque observer & {$[\mathrm{rad} / \mathrm{s}]$} & 10.0 \\
\hline
\end{tabular}

荷の角速度推定手法の有効性を検証するため実験を行った。 実験には図 1 に示す実験システムを用いた。

$\langle\mathbf{5} \cdot \mathbf{1}\rangle$ 実験方法 従来の手法 ${ }^{(8)}$ と本論文で提案した 慣性トルク推定オブザーバを用いる手法の 2 通りの手法で 吊り荷の角速度を推定し，振動制御を行った。実験装置と 制御系のパラメータをそれぞれ表 1 , 表 2 に示す。従来法

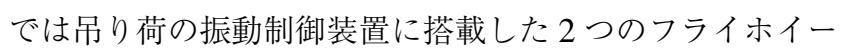
ルのうちの一方を吊り荷の角速度推定に用いる必要がある ため，もう一方のみで振動制御を行った。これに対し，提

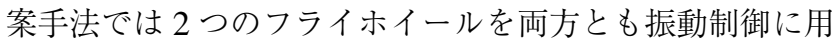
いた。そして吊り荷の角速度の推定值を実測值と比較し, 推定の精度を評価した。吊り荷の角度と角速度の実測值は ジャイロセンサを用いて測定した。

$\langle\mathbf{5} \cdot \mathbf{2}\rangle$ 実験結果 まず吊り荷の振動制御に必要な角 速度の推定結果について述べる。図 7, 図 9 にそれぞれ従来 法, 提案手法を用いた場合の吊り荷の角速度 $\dot{\phi}$ とその推定 值 $\hat{\dot{\phi}}$ を示す。図 7 より，従来法を適用した場合は吊り荷の 角速度をほぼ正確に推定できていることが確認できた。繰 り返し実験を行った結果, 提案手法を用いて 1 つのフライ ホイールで吊り荷の角速度の推定と振動制御を同時に行っ た場合，吊り荷の角速度の振幅がおよそ $0.15 \mathrm{rad} / \mathrm{s}$ 以下（吊 り荷の角度の振幅がおよそ $0.025 \mathrm{rad}$ 以下）になったときに 角速度の推定值が正確でなくなってしまうことが判明した。 フライホイールに加わる慣性トルクは非常に小さく摩擦卜 ルクよりも低い值であるため，トルクリプルによる外乱卜 ルクや摩擦トルクの同定誤差, エンコーダの性能が慣性卜 ルクの正確な推定に大きく影響を及ぼしていると考えられ る。また，振動制御を行っている状態ではモータへの入力 がステップ状になるので，制御系が不安定になったことも 想定される。振動制御のための反動トルクを出力しない場 合には，振動がほぼ停止しても慣性トルク推定オブザーバ 


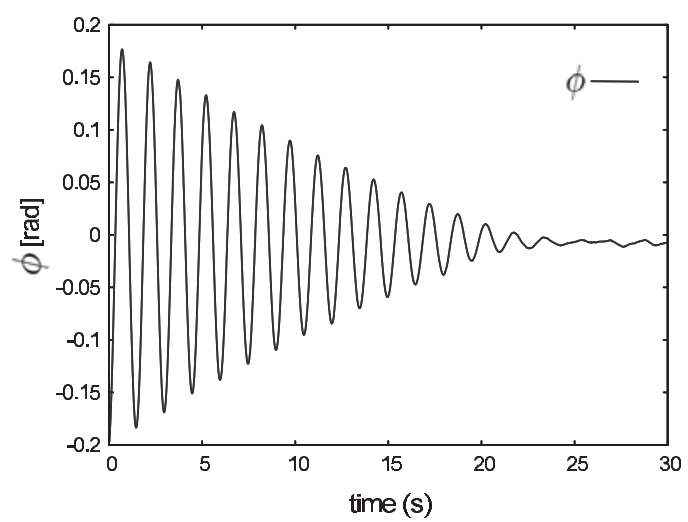

図 6 角度応答 (従来法)

Fig. 6. Position responce (Conventional method).

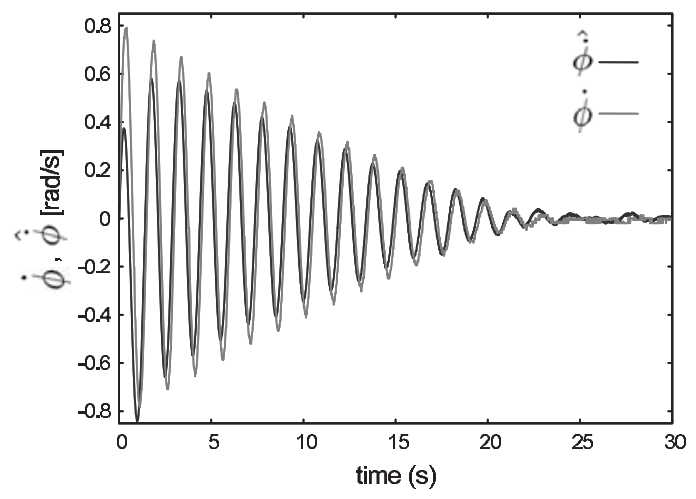

図 7 角速度の推定（従来法）

Fig. 7. Estimation of angular velocity (Conventional method).

により吊り荷の角速度を正確に推定可能という結果が出て いる。そこで，本実験では吊り荷の角速度推定值の振幅が $0.15 \mathrm{rad} / \mathrm{s}$ 以下になったときには振動制御装置に搭載した

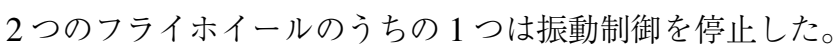
そして，等速で回転するように制御を切り替えることで吊 り荷の角速度を正確に推定できるようにした。吊り荷の角 速度推定值が $0.15 \mathrm{rad} / \mathrm{s}$ 以下になったあとは，振動制御を 停止したフライホイールによる推定值をもう 1 つのフライ ホイールの制御入力として振動制御を続けた。図 9 で一時 的に角速度の推定值が正確でなくなっているのは制御の切 り替えが行われたためである。それ以外では吊り荷の角速 度を正確に推定できていることが確認できた。

次に吊り荷の振動制御の結果について述べる。図 6, 図 8 にそれぞれ従来法，提案手法を用いた場合の吊り荷の角度 $\phi$ の応答を示す。吊り荷の角度の振幅が $0.01 \mathrm{rad}$ 以下になっ たとき，振動が止まったと判断する。従来法では振動が止 まるまで約 22 秒かかったのに対し，提案手法では約 15 秒 しかかからなかったことが確認できた。これは，従来法で はただ 1 つのライホイールしか振動制御に用いることが できなかったのに対し，提案手法では振動制御装置に搭載

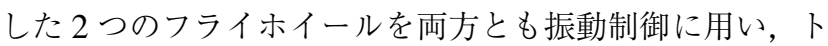
ルクの高出力化が可能になったためである。提案手法を適

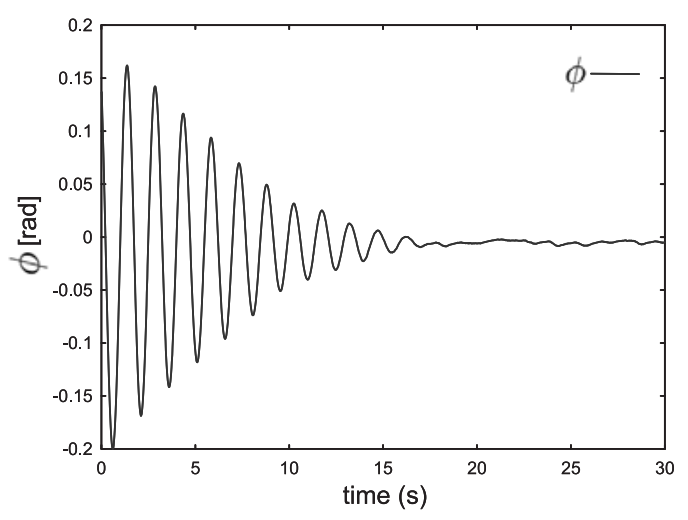

図 8 角度応答 (提案手法)

Fig. 8. Position responce (Proposed method).

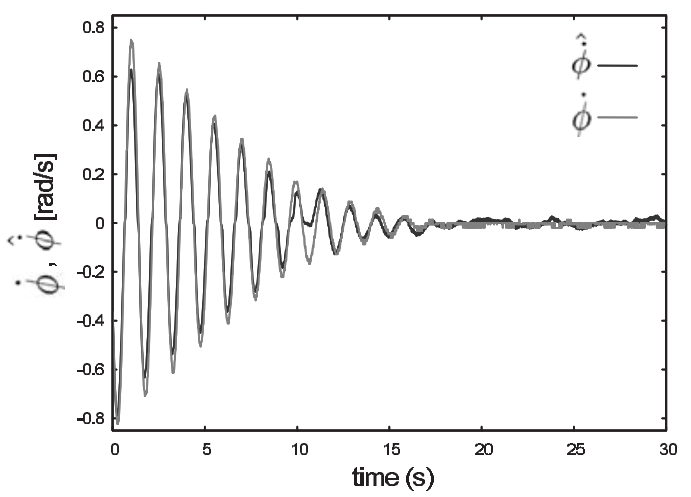

図 9 角速度の推定（提案手法）

Fig. 9. Estimation of angular velocity (Proposed method).

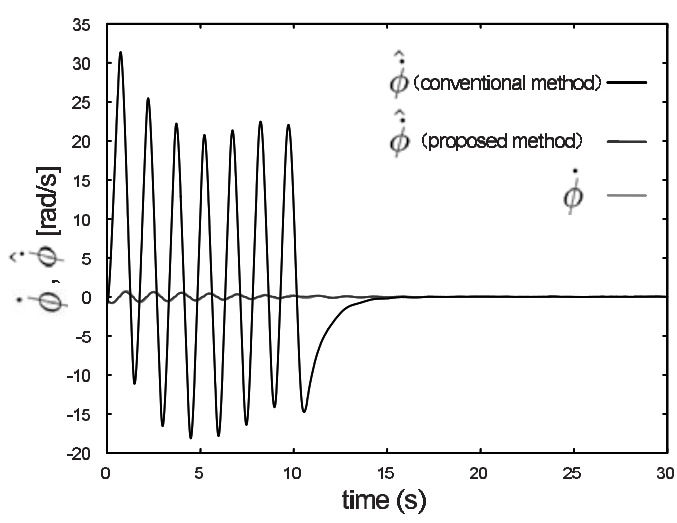

図 10 角速度の推定精度の比較

Fig. 10. Accuracy of angular velocity estimation.

用した場合の吊り荷の振動が止まるまでにかかる時間が単 純に従来法を適用した場合の半分になっていないのは，制御 の切り替え時に角速度推定值が正確でなくなったことと吊 り荷の支持点に加わる摩擦の影響が原因として考えられる。 また，本実験では提案手法で吊り荷の振動制御を行った 際に，振動制御を行うフライホイールに従来法による角速 度推定を同時に適用した。その結果を図 10 に示す。従来 法による推定值は実測值と大きく異なる值を示したのに対 し，提案手法による推定值は実測值とほぼ一致している。 
したがって，提案手法では吊り荷の角速度の推定精度が従 来法と比較して飛躍的に向上したことが確認できた。従来 法では吊り荷が振動することによるフライホイールの角速 度の変化をバンドパスフィルタを用いて抽出し，吊り荷の 角速度を推定している。振動制御のためのトルクの出力に よりフライホイールの角速度は大きく变動するが，この周 波数は吊り荷の振動と同じである。このためトルクの出力 による角速度の变動が吊り荷の角速度推定值としてそのま ま表れてしまい，正確な推定ができなかったと考えられる。

吊り荷の角速度の推定精度がさらに向上し吊り荷の振動 が微小になった際にも正確な推定ができるようになれば, 角速度推定用のフライホイールを外しても振動制御ができ るので，振動制御装置の軽量化も可能である。

\section{6. トルクリプルに対するロバスト性の検証}

提案した慣性トルク推定オブザーバによる吊り荷の角速 度推定手法のトルクリプルに対するロバスト性を検証する ため, シミュレーションを行った。このシミュレーション では 2 つフライホイールを両方とも振動制御に用いた。 意図的にトルク定数 $K_{t}$ を变化させ，吊り荷の角速度の推定 值を実際の値と比較し，推定のロバスト性について検証し た。実験で用いたモータドライバ（サーボテクノ株式会社 製，PMA6）の電流制御の仕様は誤差が $1.0 \%$ 以下であるの で，ここでは $K t$ が $0.5 \% ， 1.0 \%$ オフセット誤差を含む場

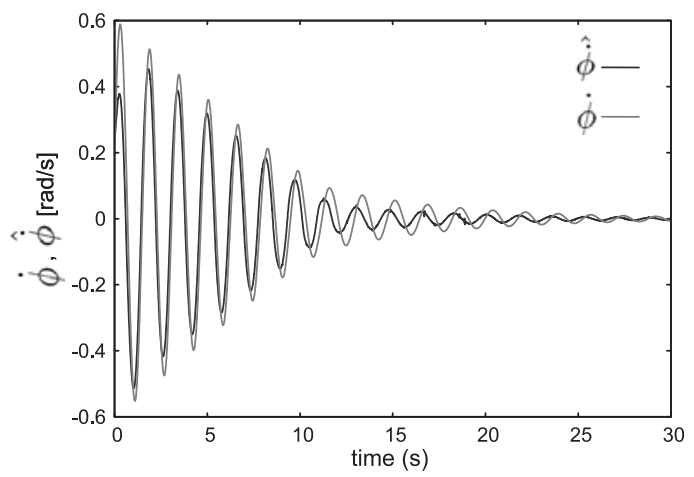

図 11 オフセット誤差 $0.5 \%$

Fig. 11. Offset error $0.5 \%$.

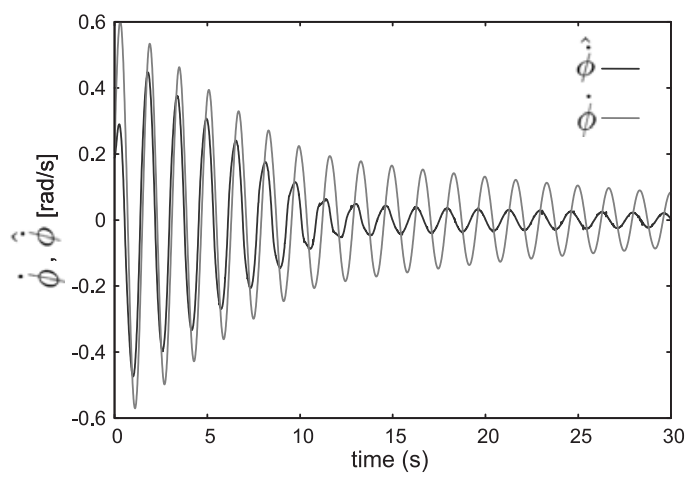

図 12 オフセット誤差 $1.0 \%$

Fig. 12. Offset error $1.0 \%$.
合と, $1.0 \%, 5.0 \%$ 以内でランダムに変動する誤差を含む場 合についてシミュレーションを行った。シミュレーション で用いた各パラメー夕は第 5 章の実験と同様である。

図 11，図 12 は Kt が $0.5 \% ， 1.0 \%$ オフセット誤差を含 む場合の角速度の推定結果である。どちらも吊り荷の振動 が小さくなるにしたがって推定䛊差が大きくなっているの がわかる。吊り荷の振動が小さくなるにつれ吊り荷がフラ イホイールに与える慣性トルクも小さくなり，トルク定数 の誤差の影響が大きくなるためである。 $K_{t}$ が $0.5 \%$ オフ セット誤差を含む場合は吊り荷の振動は約 18 秒で止まっ たのに対し，1.0\%の場合は吊り荷の振動は定常的に残って しまった。本論文で提案した手法は，一定のオフセット誤 差にはそれほどロバストではないといえる。しかし， $K_{t}$ の オフセット誤差はモータドライバを調整することで簡単に 除去できるので，十分対応可能である。

図 13，図 14 は Kt が 1.0\%，5.0\%以内でランダムに変動 する誤差を含む場合の角速度の推定結果である。どちらの 場合も吊り荷の角速度を正確に推定でき，振動は約 13 秒で 止まった。ランダムに変動する誤差は周波数が高く, (14), (16) 式に含まれるローパスフイル夕によって除去されたた めである。一般的なモータドライバの電流制御の性能は誤 差が $1.0 \%$ 以内であるので，高周波の誤差が 5.0\%以内でも 吊り荷の角速度を正確に推定できたことから，提案手法は 高周波の誤差に対してロバストであるといえる。

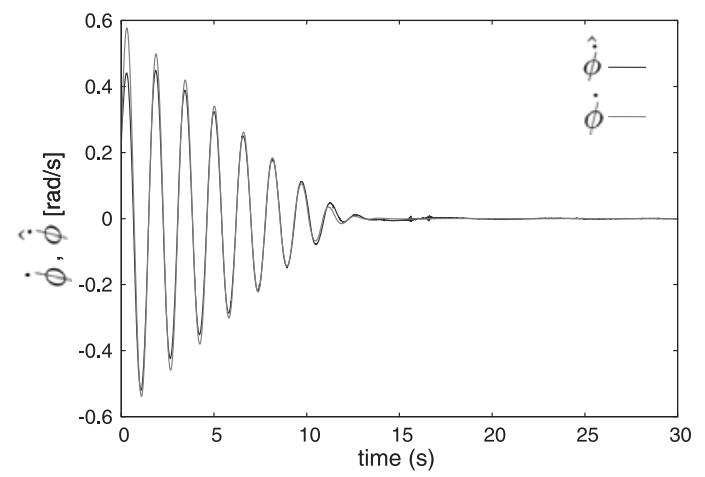

困 13 ランダム誤差 $1.0 \%$

Fig. 13. Random error $1.0 \%$.

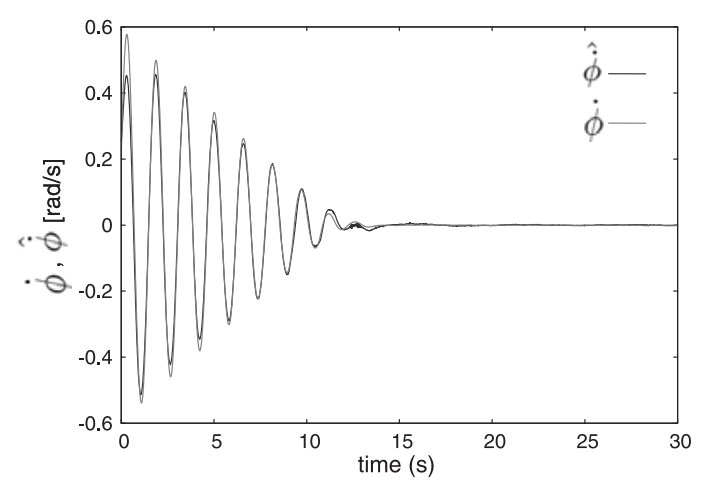

図 14 ランダム誤差 $5.0 \%$

Fig. 14. Random error 5.0\%. 


\section{7. 結 論}

本論文ではフライホイールを用いて吊り荷のセンサレス 振動制御を行った。外乱オブザーバの推定する外乱から慣 性トルクを抽出する慣性トルク推定オブザーバを提案した。 これを用いて吊り荷の角速度を推定することができた。慣 性トルク推定オブザーバをフライホイールの制御系に適用 し，1つのフライホイールで吊り荷の角速度推定と振動制 御を同時に行うという従来法の課題を克服した。従来法で 吊り荷の角速度推定に用いていたフライホイールを振動制 御に利用でき，この結果トルクの高出力化を実現した。吊 り荷の振動が微小である場合にも正確な角速度推定が可能 になれば，角速度推定用のフライホイールを取り除くこと ができ，振動制御装置の軽量化も図れる。また，トルクリ プルに対する提案手法のロバスト性についても検証し， ト ルク定数の高周波の誤差に対してのロバスト性を確認した。

本論文で提案した手法により，港湾や建設現場における荷 物の積み下ろし作業の効率化や安全性の向上が期待できる。

(平成 17 年 9 月 8 日受付，平成 18 年 2 月 28 日再受付)

\section{文献}

(1) W.E. Singhose, L.J. Porter, and W.P. Seering: "Input Shaped Control of a Planer Gantry Crane with Hoisting", Proc. of American Control Conference, pp.97-100 (1997)

(2) H. Aschemann, O. Sawodny, and E.P. Hofer: "Active Damping of Tilt Oscillations and Trajectory Control of Overhead Cranes", Proc. of the 26th Annual Conf. of the IEEE IE Soc., Vol.1, pp.70-75 (2000)

(3) Y. Fang, W.E. Dixon, D.M. Dawson, and E. Zergeroglu: "Nonlinear Coupling Control Laws for an Underactuated Overhead Crane System", IEEE/ASME Trans. on Mech., Vol.8, No.3, pp.418-423 (2003-3)

(4) H. Kanki, Y. Nekomoto, F. Inoue, K. Fukuda, Y. Ikeda, and T. Wakisada: "Development of Suspender Controlled by CMG", Proc. of JSME DMC Division, Vol.95, No.8, (I), B, pp.34-37 (1995-8) (in Japanese)

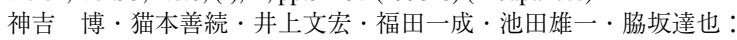
$\lceil\mathrm{CMG}$ クレーン用吊り荷制御装置の開発」, 機学機械力学・計測制御 全大, 95, 8, (I), B, pp.34-37 (1995)

( 5 ) Y. Yoshida and M. Yajima: "Control of Rotation and Swing of a Rigid Body Suspended Load Using Inertia Rotors", J. of JSME, Vol.69, No.677, pp.6368 (2003) (in Japanese)

吉田靖夫 ・矢島三代佳 :「慣性ロー夕を用いた剛体吊り荷の回転と 摇れの防止制御」, 機学論 (C), 69, 677, pp.63-68 (2003)

(6) T. Tsuji and K. Ohnishi: "A Mechanism on Attitude Control Device for Flying Object”, Proc. IEEE Int. Conference on Ind. Tech., pp.250-255 (2003)

(7) T. Tsuji, K. Nishimura, and K. Ohnishi: "Performance Assessment of Attitude Control Device with Flywheels", The Papers of Tech. Meeting on Ind. Instrumentation and Control, IEE Japan, IIC-05-07 (2005) (in Japanese) 辻 俊明・大西公平:「フライホイールを用いた姿勢制御装置の性 能評価」, 電学産業計測制御研資, IIC-05-07 (2005)

(8) T. Tsuji and K. Ohnishi: "Oscillation Control of Suspended Load with Flywheels", Proc. of the 2004 JIASC, pp.465-470 (2004) (in Japanese) 辻 俊明・大西公平:「フライホイールによる吊り荷の振動制御」, 電 学産業応用部門全大, pp.465-470 (2004)

(9) K. Ohnishi: "Robust Motion Control by Disturbance Observer", J. of RSJ, Vol.11, No.4, pp.486-493 (1993-4) (in Japanese) 大西公平：「外乱オブザーバによるロバスト・モーションコントロー ル」, 日本ロボット学誌, Vol.11, No.4, pp.486-493 (1993-4)

(10) T. Murakami, F. Yu, and K. Ohnishi: "Torque Sensorless Control in Multidegree-of-Freedom Manipulator", IEEE Trans. on IE, Vol.40, pp.259265 (1993)

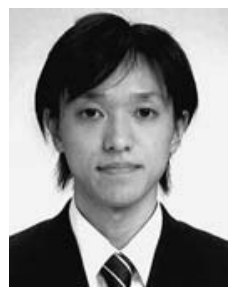

(学生員) 1983 年 1 月 1 日生。 2005 年 3 月慶應 義塾大学理工学部システムデザイン工学科卒業。 同年 4 月同大学大学院理工学研究科総合デザイン 工学専攻前期博士 (修士) 課程入学。主としてロ ボットマニピュレータのモーションコントロール に関する研究に従事。

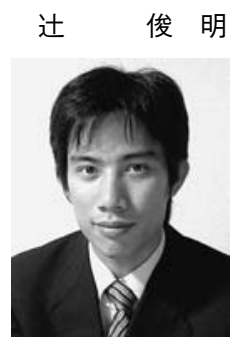

（正員） 1978 年 7 月 9 日生。 2006 年 3 月慶應義 塾大学大学院理工学研究科総合デザイン工学専攻 後期博士課程終了。現在, 東京理科大学工学部第 一部機械工学科助手。博士 (工学)。主としてロ ボティクス，モーションコントロールに関する研 究に従事。

（上級会員） 1952 年 7 月 25 日生。1980 年 3 月

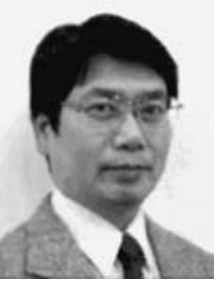
東京大学大学院工学系研究科電気工学専攻博士課 程修了。同年 4 月慶應義塾大学理工学部電気工学 科助手。現在, 理工学部システムデザイン工学科 教授。工学博士。 